Crop Breeding and Applied Biotechnology 15: 203-209, 2015

Brazilian Society of Plant Breeding. Printed in Brazil

\title{
ARTICLE
}

http://dx.doi.org/10.1590/1984-70332015v15n4a36

\section{Inheritance of resistance to papaya ringspot virus-watermelon strain (PRSV-W) in 'Whitaker' summer squash line}

\author{
Cícero B Menezes ${ }^{1}$, Wilson R Maluf ${ }^{*}$, Marcos V Faria ${ }^{3}$, Sebastião M Azevedo ${ }^{4}$, Juliano T V Resende ${ }^{3}$, Antonia R Figueira ${ }^{5}$
} and Luiz A A Gomes ${ }^{2}$

Received 16 November 2013

Accepted 24 March 2015

\begin{abstract}
The objective of this work was to study the genetic control of the PRSV-W (Papaya Ringspot Virus - Watermelon Strain) resistance in Cucurbita pepo 'Whitaker' line. Plants of parental lines Whitaker (resistant) and Caserta (susceptible), and of the generations $F_{1}, F_{2}, B C_{11}$ and $B C_{12}$ were evaluated for their reactions to PRSV-W. Caserta plants showed severe mosaic symptoms, while Whitaker grew vigorously and remained almost totally symptom-free. Most of the $F_{p}, F_{2}$ and backcross plants also presented severe mosaic symptoms. Data were used to test a hypothesis of monogenic inheritance under different presumed degrees of dominance, and genetic models were tested using maximum likelihood tests of genetic control. Broad-sense heritability was of 0.57 for the first evaluation. Resistance to PRSV-W in C. pepo 'Whitaker' is due to a major gene effect summed to polygenic effects.
\end{abstract}

Key words: Cucurbita pepo, genetic control, potyvirus, virus resistance.

\section{INTRODUCTION}

PRSV-W (Papaya Ringspot Virus - Watermelon Strain) affects all agricultural Cucurbitaceae species, achieving great economic importance due to its destructiveness. The virus is transmitted in a non-persistent manner by numerous species of aphids, including Myzus persicae and Aphis spp. (Vieira et al. 2010). It has become one of the most limiting factors for cucurbit crops in warm climate countries like Brazil, where aphids can easily survive throughout the year (Nascimento et al. 2011). Virus symptoms vary from chlorotic spots and mosaic to distortions, mainly in apical leaves. Flower deformations and fruit inhibition can be observed as well.

Higher virus disease incidence is related to greater aphid populations (Bateson et al. 2002). PRSV-W control is very difficult, and the method that has been widely used is the insecticide sprays to eliminate virus vectors. Cross protection with mild strain of the virus has been tested with some success, but it needs further studies before it can be recommended to farmers, due to its possible synergistic effect when the plants are infected by more than one virus. Genetic resistance appears to be the ideal virus control strategy, both economically and environmentally (Rezende and Muller 1995).

Genetic resistance has been found in Cucurbita ecuadorensis, C. maxima, C. foetidissima and C. moschata squash species. However, resistant sources have not been found in C. pepo (Maluf et al. 1986, Kuabara et al. 1987). 'Whitaker' was the first $C$. pepo line reported as resistant; it was developed at the Cornell University through interspecific crossing, and its resistance derives from C. ecuadorensis (Robinson and Reiners 1999).

Inheritance of PRSV-W resistance has been elucidated in other cucurbit crops, such as muskmelons (Pitrat and Lecoq 1983) and watermelons (Azevedo et al. 2012, Alves et al. 2014). Resistance in C. maxima and C. moschata is controlled by more than one gene. Kuabara et al. (1987) studied the inheritance of resistance to PRSV-W in $C$. maxima, and suggested control by at least two recessive alleles in different loci. The resistance of the line "Varzea

\footnotetext{
${ }^{1}$ Embrapa Milho e Sorgo, MG 424, km 45, 35.701-970, Sete Lagoas, MG, Brazil

${ }^{2}$ Universidade Federal de Lavras (UFLA), Departamento de Agricultura, CP 37, 37.200-000, Lavras, MG, Brazil. *Email: wrmaluf@dag.ufla.br

${ }^{3}$ Universidade Estadual do Centro Oeste (UNICENTRO), Departamento de Agronomia, Campus CEDETEG, CP 3010, 85.040-080, Guarapuava, PR, Brazil

${ }^{4}$ Sakata Seed Sudamerica, Estrada da Bocaina, s/n, 12.906-840, Bragança Paulista, SP, Brazil

${ }^{5}$ UFLA, Departamento de Fitopatologia
} 
Alegre' (C. maxima) is controlled by one or few genes with additive effect (Maluf et al. 1985). Inheritance of PRSW-V resistance was studied in two C. maxima resistant accessions (ABL-010 and Redlands Trailblazer). Both accessions were crossed with Buttercup, which is a standard cultivar of susceptibility to PRSV. Resistance presented in Redlands Trailblazer is controlled by at least two genes with additive effects. ABL-010 resistance can be explained by the action of three genes with partial dominance. Susceptible plants were found in the segregating population of the cross between ABL-010 x Redlands Trailblazer (transgressive segregation), indicating that at least one of the loci involved in the control of the resistance in ABL-010 was not allelic to their counterpart loci in Redlands Trailblaizer (Maluf et al. 1997). 'Baiana Tropical' (C. moschata) resistance was found to be controlled by two or three genes with additive effects (Oliveira et al. 2003).

Even though PRSV-W resistance in C. pepo 'Whitaker' has been reported (Nogueira et al. 2011), its mode of inheritance has not been established yet. This study reports on the mode of inheritance of PRSV-W resistance in Whitaker C. pepo line.

\section{MATERIAL AND METHODS}

The experiment was carried out in the greenhouses of the Vegetable Research Station of HortiAgro Sementes S.A., Ijaci (lat $21^{\circ} 09^{\prime} 24^{\prime}$ ' S, long $44^{\circ} 55^{\prime} 34^{\prime}$ ' W, alt $833 \mathrm{~m}$ asl), MG, Brazil. Whitaker $\left(\mathrm{P}_{1}\right)$ and Caserta $\left(\mathrm{P}_{2}\right)$ were used as parents in a cross designed to study the inheritance of PRSV-W resistance. Whitaker is a line reportedly resistant to three viruses: Papaya ringspot virus - watermelon strain (PRSV-W), Cucumber mosaic virus (CMV), Zucchini yellow mosaic virus (ZYMV). Whitaker resistance to PRSV-W is derived from C. ecuadorensis (Robinson and Reiners 1999). Caserta is a PRSV-W susceptible C. pepo standard cultivar widely grown in Brazil. $F_{1}$ (Whitaker $x$ Caserta) plants were both self-pollinated to produce $\mathrm{F}_{2}$ generation, and crossed to both parents to produce the reciprocal backcross families $\mathrm{BC}_{11}\left(\right.$ Whitaker $\left.\mathrm{x} \mathrm{F}_{1}\right)$ and $\mathrm{BC}_{12}\left(\right.$ Caserta $\left.\mathrm{x}_{1}\right)$.

Plants of the different generations were grown in soil in beds placed in a randomized design with three replications, totaling 45 Whitaker plants, 90 Caserta plants, $90 \mathrm{~F}_{1}$ plants, $360 \mathrm{~F}_{2}$ plants, $135 \mathrm{BC}_{11}$ plants (Whitaker $\mathrm{x}_{1}$ ) and $180 \mathrm{BC}_{12}$ plants $\left(\right.$ Caserta $\left.x \mathrm{~F}_{1}\right)$, which were evaluated for their reactions to mechanical inoculation with PRSV-W.

A Brazilian isolate of PRSV-W (identified at the Department of Plant Pathology of Universidade Federal de Lavras, Lavras, MG, Brazil) was multiplied in C. pepo cv. Asmara. Just before inoculation, inoculum was prepared by grinding infected leaves with mortar and pestle in $0.01 \mathrm{M}$ phosphate buffer, $\mathrm{pH} 7.0$, with $0.1 \%$ sodium sulfite. Buffer $\mathrm{x}$ leaf ratio was 9:1 ( $9 \mathrm{~mL}$ of buffer for every 1 gram of infected leaf). Two inoculations were carried out: the first when the seedlings were nine days old, and the second, twelve days after the first one. Inoculation consisted of lightly dusting the cotyledonary leaves with 400-mesh carborundum, and then mechanically rubbing the inoculum with the forefinger. After inoculation, carborundum was rinsed off of the leaves with water.

Plant symptoms were rated at 10, 17 and 24 days after inoculation, using a scores from 1 to 5 , adapted from Oliveira et al. (2003), as follows: $1=$ no visible symptoms; $2=$ most leaves with no symptoms; one or a few leaves with mild symptoms, mostly clear veins; 3 = most leaves with mosaic; symptoms varying from vein clearing to sparse chlorotic spot to chlorosis in up to $50 \%$ of the leaf area; $4=$ almost all leaves with systemic mosaic coalescence of chlorotic areas, reaching up to $50 \%$ of the leaf area; $5=$ almost all leaves with severe mosaic, at least one leaf with more than $50 \%$ of its area affected or severely distorted.

Means and variances were calculated for each one of the six populations, in order to calculate genetic parameters. Environmental variance $\left(\hat{\sigma}_{E}^{2}\right)$ was estimated as the geometric mean of the variances of $\mathrm{P}_{1}, \mathrm{P}_{2}$ and $\mathrm{F}_{1}$ generations. Genetic variance $\left(\hat{\sigma}_{G}^{2}\right)$, and its additive $\left(\hat{\sigma}_{A}^{2}\right)$ and dominance $\left(\hat{\sigma}_{D}^{2}\right)$ components, as well as broad sense heritability $\left(H^{2}\right)$ were estimated (Mather and Jinks 1977). Generation mean analysis was carried out based on the data by the weighted least squares method (Mather and Jinks 1977), in order to test the fitness of a simple additive-dominant model, and to estimate the mean degree of dominance (MDD).

Data were used to test a hypothesis of monogenic inheritance under different presumed degrees of dominance, as described by Gomes et al. (2000) and Menezes et al. (2005).

A truncation point (TP) was chosen in the symptom scale, so that most of $\mathrm{P}_{1}$ plants were below the TP and most of $\mathrm{P}_{2}$ plants were above it. The TP used was score 2.0. Hypothesis of monogenic inheritance was tested following some suppositions and procedures:

a) Data from all generations $\left(\mathrm{P}_{1}, \mathrm{P}_{2}, \mathrm{~F}_{1}, \mathrm{~F}_{2}, \mathrm{BC}_{11}\right.$ and $\left.\mathrm{BC}_{12}\right)$ have a normal distribution.

b) Means and variances of $\mathrm{P}_{1}$ and $\mathrm{P}_{2}$ are equal to the respective estimates obtained from the experimental data.

c) Based on normal distribution, frequencies of $P_{1}$ and $P_{2}$ plants with scores equal or lower than the truncation point were estimated. 
d) The mean of $\mathrm{F}_{1}$ generation was admitted as being: $\bar{F}_{1}$ $=\left(\bar{P}_{1}+\bar{P}_{2}\right) / 2+\operatorname{MDD}\left(\bar{P}_{2}-\bar{P}_{1}\right) / 2$, where $\bar{P}_{1}$ and $\bar{P}_{2}$ are the respective parental means, and MDD is the mean degree of dominance presumed.

(e) The variance of the $F_{1}$ population is equal to the respective variance estimate obtained from the experimental data.

f) The expected frequencies of $\mathrm{F}_{2}, \mathrm{BC}_{11}$ and $\mathrm{BC}_{12}$ population, based on a monogenic model of inheritance, were estimated as functions of $\mathrm{P}_{1}, \mathrm{P}_{2}$ and $\mathrm{F}_{1}$ frequencies, as follows:

$F_{2}=\left(P_{1}+2 F_{1}+P_{2}\right) / 4 ; B C_{11}=\left(P_{1}+F_{1}\right) / 2$ and $B C_{12}=\left(P_{2}\right.$ $\left.+F_{1}\right) / 2$.

g) The frequencies of $\mathrm{P}_{1}, \mathrm{P}_{2}, \mathrm{~F}_{1}, \mathrm{~F}_{2}, \mathrm{BC}_{11}$ and $\mathrm{BC}_{12}$ plants $£$ $\mathrm{TP}$ were calculated by multiplying the expected frequencies by the total number of plants tested per generations.

g) Expected numbers of plants £ TP were compared with their respective observed values in each generation. The significance of the deviations was estimated with a $\chi^{2}$ test, with 4 degrees of freedom. The frequency of expected plants in $\mathrm{P}_{1}$ was added to that of $\mathrm{P}_{2}$, in order to avoid expected frequencies equal to zero.

h) Significant $\chi^{2}$ values would lead to the rejection of the hypothesis of monogenic inheritance under the degree of dominance presumed. On the other hand, a non-significant $\chi^{2}$ value would lead to non-rejection of such hypothesis. Values of $\chi^{2}$ for each simulation were plotted against their respective hypothetical MDD's. The interval of MDD values of which $\chi^{2}$ values are below the $\mathrm{a}=0.05$ critical value represents the MDD interval in which the monogenic hypothesis was not rejected.

Some genetic models were tested using maximum likelihood in mixtures of normal densities, as proposed by Gonçalves et al. (2004) and Rezende et al. (2004). Based on the means and variances components (Mather and Jinks 1977), data were subjected to a normal distribution, as follows:

$P_{1}: N\left(\mu-[a]-A, \sigma^{2}\right)$

$P_{2}: N\left(\mu-[a]+A, \sigma^{2}\right)$

$F_{1}: N\left(\mu-[d]-D, \sigma^{2}\right)$

$F_{2}: \frac{1}{4} N\left(\mu+\frac{[d]}{2}-A, \sigma^{2}+V_{A}+V_{D}\right)+\frac{1}{2} N\left(\mu+\frac{[d]}{2}+D, \sigma^{2}+V_{A}+V_{D}\right)+$ $\frac{1}{4} N\left(\mu+\frac{[d]}{2}+A, \sigma^{2}+V_{A}+V_{D}\right)$

$B C_{11}: \frac{1}{2} N\left(\mu+\frac{[a]}{2}+\frac{[d]}{2}-A, \sigma^{2}+\frac{V_{A}}{2}+V_{D}-S_{A D}\right)+\frac{1}{2} N\left(\mu-\frac{[a]}{2}+\right.$
$\left.\frac{[d]}{2}+D, \sigma^{2}+\frac{V_{A}}{2}+V_{D}-S_{A D}\right)$

$B C_{12}: \frac{1}{2} N\left(\mu+\frac{[a]}{2}+\frac{[d]}{2}+A, \sigma^{2}+\frac{V_{A}}{2}+V_{D}+S_{A D}\right)+\frac{1}{2} N\left(\mu+\frac{[a]}{2}+\right.$

$\left.\frac{[d]}{2}+D, \sigma^{2}+\frac{V_{A}}{2}+V_{D}+S_{A D}\right)$

where:

$\mu$ : Constant of reference

$A$ : Additive effect of the major gene

$D$ : Dominance effect of the major gene

[a]: Polygenic additive effect

$[d]$ : Polygenic dominance effect

$V_{A}$ : Additive variance

$V_{D}$ : Dominance variance associated with polygenic effects

$S_{A D}$ : Additive x dominance deviation associated with polygenic effects

$\sigma^{2}$ : Environmental variance

Normal distributions of $\mathrm{BC}_{11}$ and $\mathrm{BC}_{12}$ are composed by two normal densities and of $\mathrm{F}_{2}$ by three normal densities.

Tests using maximum likelihood were made via LR (Gonçalves et al. 2004):

$L R=-2 \ln \frac{L\left(M_{i}\right)}{L\left(M_{i}\right)}$,

where $L\left(\mathrm{M}_{\mathrm{i}}\right)$ and $L\left(M_{j}\right)$ are maximum likelihood functions of the models $\mathrm{i}$ and $\mathrm{j}$, and model $\mathrm{i}$ should be hierarchal to model j.

For the analyses, the full genetic model admitted a major gene with additive and dominance effects, and polygenes, also with additive and dominance effects. From the complete genetic model, simpler models containing less parameters were generated (Table 1). Environmental variances were considered equal for all generations, and gene segregation was considered independent (both major genes and polygenes). Hypothesis tests of the genetic parameters were carried out based on likelihood ratio between two models (Gonçalves et al. 2004). The tests were carried out using the statistical software 'Monogen v.0.1'.

\section{RESULTS AND DISCUSSION}

Fast evolution of symptoms was observed from the first to the last evaluation (Tables 2 and 3). Some 'Whitaker' plants showed sparse chlorotic spots, due to the high virus concentration and multiplication. By that time, all susceptible plants had already died. General average score for Whitaker 
was 2.0, whereas cultivar Caserta had already showed a score of about 4.0 at the first evaluation date. These data show the contrasting levels of resistance of the two parental lines involved. All Caserta plants died with severe viral symptoms, while those of Whitaker grew vigorously and remained almost totally symptom-free (Table 2).
Infected leaves of Caserta and Whitaker were used as inoculum in back inoculation in Caserta plants, in order to check for virus recovery. Caserta plants back inoculated with inocula from both parental lines presented PRSV-W symptoms, indicating that the mechanism of resistance to PRSV-W imparted by Whitaker is probably tolerance.

Table 1. Genetic inheritance models according to Rezende et al. (2004) tested for resistance to PRSV-W in summer squash

\begin{tabular}{lr}
\hline Models & Estimated parameters \\
\hline 1 = major gene with additive and dominance effects + polygenes with additive and dominance effects & $\mu, A, D,[a],[d], V_{A}, V_{D}, S_{A D}, \sigma^{2}$ \\
2 = major gene with additive and dominance effects + polygenes with only additive effect & $\mu, A, D,[a], V_{A}, \sigma^{2}$ \\
3 = major gene with only additive effect + polygenes with additive and dominance effects & $\mu, A,[a],[d], V_{A}, V_{D}, S_{A D}, \sigma^{2}$ \\
$4=$ major gene with only additive effect + polygenes with only additive effect & $\mu, A,[a], V_{A}, \sigma^{2}$ \\
$5=$ polygenes with additive and dominance effects & $\mu,[a],[d], V_{A}, V_{D}, S_{A D}, \sigma^{2}$ \\
$6=$ polygenes with only additive effect & $\mu,[a], V_{A}, \sigma^{2}$ \\
$7=$ major gene with additive and dominance effects & $\mu, A, D, \sigma^{2}$ \\
$8=$ major gene with only additive effect & $\mu, A, \sigma^{2}$ \\
9 & $=$ only environmental effects \\
\hline
\end{tabular}

Table 2. Means and variances for resistance to PRSV-W in summer squash (Cucurbita pepo), in three evaluation dates (10, 17 and 24 days) after inoculation

\begin{tabular}{|c|c|c|c|c|c|c|}
\hline \multirow[b]{2}{*}{ Generation } & \multicolumn{2}{|c|}{10 days } & \multicolumn{2}{|c|}{17 days } & \multicolumn{2}{|c|}{24 days } \\
\hline & Mean & Variance & Mean & Variance & Mean & Variance \\
\hline Whitaker & 1.07 & 0.0623 & 1.35 & 0.4097 & 1.63 & 0.5493 \\
\hline Caserta & 3.97 & 1.4483 & 4.77 & 0.3607 & 4.96 & 0.0879 \\
\hline $\mathrm{F}_{1}$ & 2.53 & 1.6080 & 3.50 & 1.5862 & 4.77 & 0.2926 \\
\hline $\mathrm{F}_{2}$ & 3.29 & 1.2199 & 4.30 & 0.7721 & 4.84 & 0.2710 \\
\hline $\mathrm{RC}_{11}\left(\right.$ Whitaker $\left.\times \mathrm{F}_{1}\right)$ & 1.46 & 0.7092 & 2.60 & 1.6782 & 3.86 & 1.9285 \\
\hline
\end{tabular}

Table 3. Frequencies of plant symptom scores in Whitaker, Caserta, and generations $\mathrm{F}_{1}, \mathrm{~F}_{2}, \mathrm{BC}_{11}$ and $\mathrm{BC}_{12}$, in three evaluation dates $(10,17$ and 24 days) after inoculation with PRSV-W

\begin{tabular}{|c|c|c|c|c|c|c|c|c|c|c|c|c|c|c|c|c|}
\hline \multirow{3}{*}{ Generation } & \multirow{3}{*}{ TNP } & \multicolumn{5}{|c|}{10 days $(\%)$} & \multicolumn{5}{|c|}{17 days $(\%)$} & \multicolumn{5}{|c|}{24 days $(\%)$} \\
\hline & & \multicolumn{5}{|c|}{ Score } & \multicolumn{5}{|c|}{ Score } & \multicolumn{5}{|c|}{ Score } \\
\hline & & 1 & 2 & 3 & 4 & 5 & 1 & 2 & 3 & 4 & 5 & 1 & 2 & 3 & 4 & 5 \\
\hline Caserta & 90 & 7 & 3 & 15 & 26 & 39 & 0 & 2 & 2 & 11 & 75 & 0 & 0 & 2 & 0 & 88 \\
\hline $\mathrm{F}_{1}$ & 90 & 32 & 9 & 22 & 26 & 1 & 10 & 9 & 15 & 37 & 19 & 0 & 0 & 5 & 10 & 75 \\
\hline $\mathrm{F}_{2}$ & 360 & 46 & 20 & 102 & 168 & 24 & 5 & 13 & 32 & 130 & 180 & 1 & 1 & 16 & 17 & 325 \\
\hline $\mathrm{BC}_{12}\left(\right.$ Caserta $\left.\mathrm{x} \mathrm{F}_{1}\right)$ & 180 & 23 & 7 & 34 & 89 & 27 & 5 & 5 & 7 & 43 & 120 & 0 & 0 & 2 & 7 & 171 \\
\hline
\end{tabular}

TNP: Total Number of plants

Table 4. Mean components, mean degree of dominance (MDD) and broad-sense heritability $\left(\mathrm{H}^{2}\right)$ for PRSV-W symptom expression in summer squash (Cucurbita pepo), in three evaluation dates (10, 17 and 24 days) after inoculation with PRSV-W

\begin{tabular}{lccc}
\hline Parameters & 10 days & 17 days & 24 days \\
\hline $\mathrm{m}$ & $2.7343 \pm 0.1487$ & $3.2434 \pm 0.1645$ & $3.9149 \pm 0.2073$ \\
{$[a]$} & $1.6837 \pm 0.1422$ & $1.6291 \pm 0.1543$ & $1.0401 \pm 0.1916$ \\
{$[d]$} & $0.1156 \pm 0.6436$ & $1.2726 \pm 0.7319$ & $1.2026 \pm 0.5228$ \\
$\chi^{2}$ & 0.2720 & 0.3781 & 0.7068 \\
$\mathrm{MDD}$ & 0.0687 & 0.7811 & 1.1562 \\
$H^{2(\%)}$ & 56.92 & 20.15 & 10.80 \\
\hline
\end{tabular}

$m:$ parental mean

$[a]$ : additive mean effect

$[d]$ : non-additive (dominance) mean effect

$\chi^{2}$ : chi-square test for fitness of the additive-dominant model 
Broad-sense heritability estimates were not uniform among the evaluations, decreasing from the first to the third evaluation (Table 4). Selection of resistant plants is expected to be effective 10 days after inoculation $\left(H^{2}=56.92 \%\right)$, but less effective $17\left(H^{2}=20.15 \%\right)$ or $24\left(H^{2}=10.80\right)$ days after inoculation, indicating the need for better control of environmental effects in the latter evaluations. These heritability estimates are lower than those reported for resistance to PRSV-W in C. maxima and C. moschata. Maluf et al. (1985), studying the resistance of the cultivar 'Varzea Alegre' (C. maxima), found broad and narrowsense heritabilities of 0.58 and 0.57 , respectively. Maluf et al. (1997), working with C. maxima genotypes, obtained broad-sense heritabilities from 0.36 to 0.59 . Oliveira et al. (2003), studying C. moschata cultivars, observed broadsense heritabilities from 0.39 to 0.97 .

A simple additive-dominant model was able to explain the segregation data (Table 4). Since no significant deviations from the proposed model were observed by the $\chi^{2}$ test, it is supposed that there is no evidence of epistatic gene effect involved in the control of resistance to PRSV-W in 'Whitaker' line. Estimates of the mean degrees of dominance were not uniform among the evaluations (Table 4). On the first evaluation, data indicated the predominance of additive gene effects, whereas on the second and third evaluations, data indicated the predominance of dominance or partial dominance gene effects in the direction to susceptibility to PRSV-W. Maluf et al. (1997), working with C. maxima, evaluated two sources resistant to PRSV-W, and found that the resistance of ABL-10 could be explained by the action of three genes with partial dominance, and the resistance of Redlands Trailblazer was due to at least two genes with additive effects.

The estimates of $\chi^{2}$ to monogenic inheritance hypothesis could not be accepted for mean degree of dominances presumed between -1.0 and +1.0 , indicating that 'Whitaker' line's resistance to PRSV-W is controlled by more than one gene (Figure 1). Frequencies distribution presented by $\mathrm{F}_{2}$ and $\mathrm{BCs}$ were very different from what is expected from a monogenic control (Table 3). More than $80 \%$ of the $\mathrm{F}_{2}$ and $\mathrm{BC}_{12}$ plants presented scores equal to or higher than 4.0 at
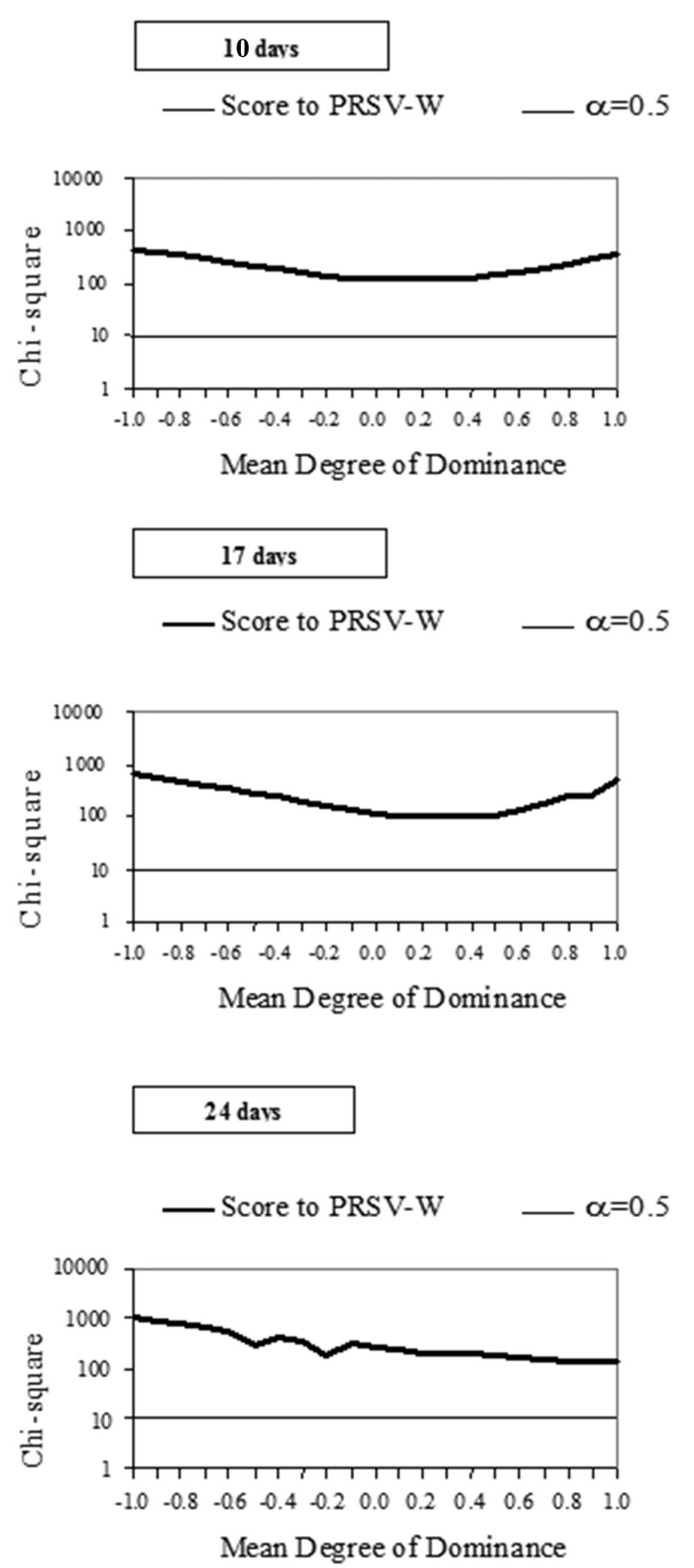

Figure 1. Monogenic hypothesis test under different presumed degrees of dominance of PRSV-W resistance in summer squash (Curcubita pepo), on three different evaluation dates (10,17 and 24 days after inoculation).

Table 5. Hypotheses of inheritance tested by using maximum likelihood for resistance to PRSV-W in summer squash, in three evaluations (10, 17 and 24 days after inoculation)

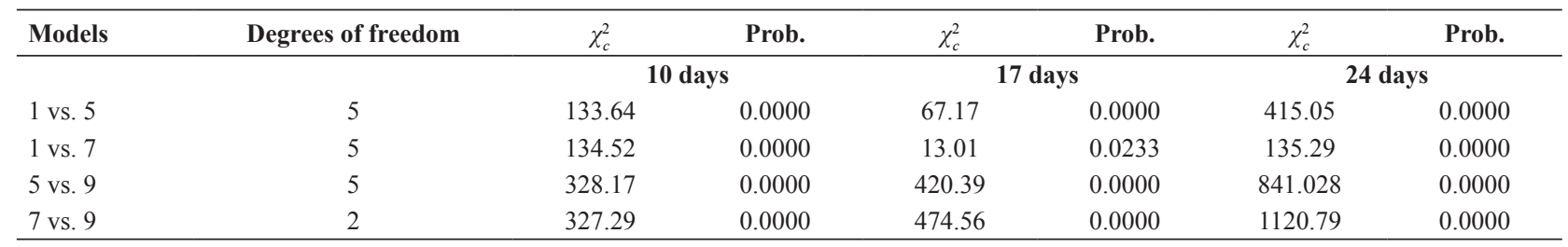


the last evaluation. Only two $\mathrm{F}_{2}$ plants were found to be resistant (Table 3).

Inheritance tests carried out with maximum likelihood tests are presented in Table 5. When model 1 is confronted to model 5, the existence of a major gene summed to polygenic effects is compared to the occurrence of polygenic effects only. The test of this hypothesis was rejected, which means that there is an effect of a major gene in the control of the trait. When model 1 is confronted to model 7 , the existence of a major gene summed to polygenic effect is compared to a model that assumes only a major gene effect. This hypothesis was also rejected, indicating the evidence of polygenic effects too. Tests confronting model 5 to model 9 , and model 7 to model 9 (Table 5) reinforce that the control of PRSV-W resistance in C. pepo 'Whitaker' is more complex than what is expected from a single major gene. There are both major gene effect and polygenic effects in the control of resistance to PRSV-W in Cucurbita pepo 'Whitaker'.

\section{Herança da resistência ao vírus da mancha anelar do mamoeiro estirpe melancia (PRSV-W) na linhagem de abobrinha 'Whitaker'}

Resumo - O objetivo do trabalho foi estudar o controle genético da resistência ao virus da mancha anelar do mamoeiro estirpe melancia (PRSV-W) na linhagem de abobrinha 'Whitaker'Cucurbita pepo. Plantas das linhagens parentais Whitaker (resistente) $e$ Caserta (suscetivel) e das gerações $F_{1}, F_{2}, R C_{11}$ e $R C_{12}$ foram avaliadas quanto aos sintomas causados pelo PRSV-W. Plantas da linhagem Caserta apresentaram sintomas severos de mosaico, enquanto as plantas de Whitaker permaneceram quase totalmente livres de sintomas. A maioria das plantas $F_{p}, F_{2}$ e dos retrocruzamentos também apresentaram sintomas severos de mosaico. Foi realizado teste de hipótese de herança monogênica sob a suposição de diferentes graus de dominância e foram testados modelos genéticos por meio de testes de máxima verossimilhança. A estimativa da herdabilidade no sentido amplo foi de 0,57 para a primeira avaliação. A resistência ao PRSV-W em C. pepo 'Whitaker'é controlada por um gene principal mais a acão de poligenes.

Palavras-chave: Cucurbita pepo, controle genético, potyvirus, resistência a virus.

\section{REFERENCES}

Alves AF, Nascimento IR, Ticona-Benavente A, Faria MV, Sarmento RA, Figueira AR and Maluf WR (2014) Herança da resistência do acesso de melancia PI 595201 a isolado de PRSV-W do Estado do Tocantins. Bragantia 73: 138-142.

Azevedo SM, Maluf WR, Faria MV, Resende JTV, Menezes CB and Nascimento IR (2012) Inheritance of resistance to the Papaya ringspot virus-watermelon strain (PRSV-W) from watermelon accession 'PI 595201'. Crop Breeding and Applied Biotechnology 12: 67-75.

Bateson MF, Lines RE, Revill P, Chaleeprom W, Ha CV, Gibbs AJ and Dale JL (2002) On the evolution and molecular epidemiology of the potyvirus papaya ringspot virus. Jornal of General Virology 83: 2575-2585.

Gomes LAA, Maluf WR and Campos VP(2000) Inheritance of the resistant reaction of the cultivar 'Grand Rapids' to the southern root-knot nematode Meloidogyne incognita (Kofoid and White) Chitwood. Euphytica 114: 37-46.

Gonçalves RP, Bearzoti E and Ferreira DF (2004) Avaliação da razão de verossimilhança generalizada em teste de hipóteses sobre o controle genético de características contínuas. Semina Ciências Agrárias 25: 281-292.

Kuabara MY, Salcedo MJG and Costa CP (1987) Fontes de resistência ao vírus do mosaico da melancia - 1 (WMV-1) em abóbora. Horticultura Brasileira 5: 20-22.

Maluf WR, Moura WM, Silva IS and Castelo-Branco M (1986) Screening of Cucurbita spp. accessions for resistance to Watermelon Mosaic Virus-1. Revista Brasileira de Genética 9: 161-167.
Maluf WR, Pereira JJ and Figueira AR (1997) Inheritance of resistance to the Papaya Ringspot Virus - Watermelon Strain in two different accessions of winter squash (Cucurbita maxima Duch.). Euphytica 94: $163-168$.

Maluf WR, Silva IS and Moura WM (1985) Inheritance of watermelon mosaic virus-1 (WMV-1) resistance in squash Cucurbita maxima Duch. Revista Brasileira de Genética 8: 174-182.

Mather K and Jinks JL (1977) Introduction to biometrical genetics. Cornell University Press, Ithaca, 231p.

Menezes CB, Maluf WR, Azevedo SM, Faria MV, Nascimento IR, Nogueira DW, Gomes LAA and Bearzoti E (2005) Inheritance of parthenocarpy in summer squash (Cucurbita pepo L). Genetics and Molecular Research 4: 39-46.

Nascimento IR, Santos LB, Figueira AR, Aguiar RWS, Maluf WR and Oliveira GIS (2011) Identificação molecular de espécies de vírus e reação fenotípica de famílias de melancia a um isolado do vírus da mancha anelar do mamoeiro, estirpe melancia (Papaya ringspot virus, watermelon strain). Journal of Biotechnology and Biodiversity 2: 22-29.

Nogueira DW, Maluf WR, Figueira AR, Maciel GM, Gomes LAA and Ticona CA (2011) Combining ability of summer-squash lines with different degrees of parthenocarpy and PRSV-W resistance. Genetics and Molecular Biology 34: 616-623.

Oliveira ACB, Maluf WR, Pinto JEBP and Azevedo SM (2003) Resistance to papaya ringspot virus in summer squash Cucurbita pepo $\mathrm{L}$. introgressed from an interspecific $C$. pepo $\times$ C. moschata cross. Euphytica 132: 211-215. 
Pitrat M and Lecoq H (1983) Two alleles for watermelon mosaic virus 1 resistance in melon. Cucurbit Genetics Cooperative Report 6: $52-53$.

Rezende VF, Vencovsky R, Cárdenas FEN, Silva HP, Bearzoti E and Camargo LEA (2004) Mixed inheritance model for resistance to anthracnose leaf blight in maize. Crop Breeding and Applied Biotechnology 4: 115-122.

Rezende JAM and Muller GW (1995) Mecanismos de proteção entre vírus e controle de viroses de vegetais por premunização. Revisão Anual de Patologia de Plantas 3: 185-226.

Robinson RW and Reiners S (1999) Parthenocarpy in summer squash. HortScience 34: 715-717.

Vieira JV, Ávila AC and Silva GO (2010) Avaliação de genótipos de melancia para resistência ao Papaya ringspot vírus, estipe melancia. Horticultura Brasileira 28: 7-11. 